\title{
キヌタ骨長脚の替在性病変について
}

\author{
小川明・山下公一・佐藤 喜一
}

\section{Latent Pathology of the Incus}

\section{Akira Ogawa, Koichi Yamashita and Kiichi Sato}

(Kanazawa Medical University)

The histopathology of the long process of the incus, which had caused no obvious otologic symptoms, was studied in our collection of human temporal bones.

Forty-eight of the 110 specimens $(44 \%)$ showed abnormal histopathology. The most frequently observed findings were localized bone absorption on the bone surface, which was sometimes scattered through the subperiosteum of the long process. The most severe finding was spherical bone absorption in the lenticular process.

The etiology of these pathological findings could be inflammation, remodelling or some aging factor. Because these absorbed areas were always filled with fibrous connective tissue, the outer shape of the lenticular process remained normal.

These pathological changes have no clinical significance by themselves, but following inflammation or mechanical trauma they can be contributing factors in the development of conductive deafness.

\section{はじめに}

一般に鼓膜正常な伝音難眲を呈する疾患としては，耳硬化症や先天性耳小䏍奇形があげられるほ か，頭部外傷による耳小骨離断も含まれる。さらに，幼小児期に罹患した急性中耳炎に起因したと 思われる，伝音系汇軽度の障害を示す症例が鼓膜正常な伝音難聴として存在すると考えられる。乙 のような例は，現在のとてろ報告はきわめて稀であるが，さらに，それよりも障害が一段と軽度 で，難聴を呈してはいないが病理組織学的には耳小骨に病変を有する場合がかなりあるのではない かと思われる。

この度，剖検時に無選把的に採取された側頭骨標本を観察したところ，かなり高頻度に，キヌタ 骨長脚の特に先端部に集中して多彩な病理組織所見が観察された。乙れらは生前，無症状に経過し たものと思われるが，乙れらの状態に炎症や機械的刺激が加わると容易に耳小骨連鎖異常を呈する 埸合屯考えられ，興味がもたれたので報告したい。

\section{研 究 方 法}

東京医科㐘科大学に保存されている側頭骨㮏 本110例110耳を光顕的にキ又タ骨長朋を中心に
解察した。これらは剖検時に無選択的に採取さ れたもので，年令分布と死因は表 1 のでとくで 
ある。

側䫓骨は採取後 $10 \%$ ホルマリンに梷定され， 脱灭後，脱水系列を経てセロイジン包埋し，汗

結

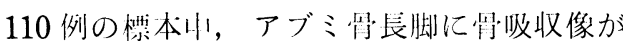
少られたむのは，48例（44\%）であった。その 稆度はさまざまで，最も多い，怪度のものは， 简膜下に郎局性にみられたものであって，これ らは多くは長朋全体に散在的にみられた（四 $1 ， 2 ， 4)$. 一j; 豆状炃起を含む長脚少端 部には，しばしば高度な骨吸収像がみられ，著 しい場合にはその部の狊質がほとんど消失して 線維組織で埋められていた（図 3，5，6， 7 )。しかしながら豆状笑起全体が消失してし まうことはなかった。骨吸収部は常に線維組織 で埋められており，そのため全体として豆状咨 起の輪郭は保たれているのが特徵的であった。 したがってての䡒吸収のために，キヌタ・アブ ミ関節の離断を生じたものはなかった。これら の省吸収像には炎症細胞の浸潤はほとんどみら れなかったし，キヌタ骨内の vascular channel や算䯣腔でも炎症細胞の浸潤や線維の増生: はなかった。これらの例の中耳粘膜を中耳全体 にわたって䚋察すると，全例で粘膜がしばしば
均約 $30 \mu \mathrm{m}$ の檿さで遇続切片が作成され， 5 枚 解にへマトキシリン・エオジン染色在施された ものである。

果

線維性に肥厚しており，その一部の例では炎为： 綝胞の汶潤屯涊められた。中耳腔内に肉芽や膿 の貯留はなかった。これらの例には战膜穿孔は みられなかったが，線維性肥厚在示すものが多 く，鼓膜皮簓層の配列の乱れなどもみられた (闵 8 ).

キヌタ省長脚に上記の所見のみられた症例を 作邻階層別に大きく 3 群に分けてみると，29才 以下の群では29例中 8 例で $28 \% ， 30 〜 49$ 才の群 では35例中17例で $49 \% ， 50$ 才以に:では，46例中 23 例と $50 \%$ の頻度を示しており，30才未満と 30 才以上では明らかに出現頻度に紊がみられた (表2 ).

表 2 年令階層別出現頻度

\begin{tabular}{|c|c|c|c|}
\hline 年令階凰 & 検索例数 & $\begin{array}{l}\text { 長脚病変 } \\
\text { 数 }\end{array}$ & 出現頻度 \\
\hline 0才〜29才 & 29 & 8 & $28 \%$ \\
\hline $30 才 \sim 49 才$ & 35 & 17 & $49 \%$ \\
\hline 50才以上. & 46 & 23 & $50 \%$ \\
\hline
\end{tabular}

表। 側頭骨の内訳

\begin{tabular}{|c|c|c|c|c|c|c|}
\hline \multirow{2}{*}{ 件 令 } & \multirow{2}{*}{ 症例数 } & \multicolumn{2}{|r|}{ 原 } & 疾 & \multicolumn{2}{|l|}{ 患 } \\
\hline & & 炎症性疾患 & 墨性腫晹 & 腎疾患 & 循環器疾患 & その他 \\
\hline $0 \sim 6 才$ & 12 & 6 & 1 & 0 & 0 & 5 \\
\hline $10 \sim 19$ & 9 & 2 & 6 & 0 & 0 & 1 \\
\hline $20 \sim 29$ & 8 & 1 & 2 & 3 & 0 & 2 \\
\hline $30 \sim 39$ & 14 & 0 & 8 & 3 & 0 & 3 \\
\hline $40 \sim 49$ & 21 & 2 & 13 & 1 & 2 & 3 \\
\hline $50 \sim 59$ & 17 & 1 & 14 & 0 & 0 & 2 \\
\hline $60 \sim 69$ & 12 & 1 & 8 & 1 & 1 & 1 \\
\hline $70 \sim 79$ & 15 & 1 & 10 & 0 & 4 & 0 \\
\hline \multirow[t]{2}{*}{$80 \sim 82$} & 2 & 0 & 1 & 0 & 1 & 0 \\
\hline & 110 & 14 & 63 & 8 & 8 & 17 \\
\hline
\end{tabular}


考

鼓膜证常な伝音難聴の川には，耳㹬化聇や先 天性耳小肖奇形之は考えられず，また韻部外傷 の既往むない例があることが利られている。芒

くは Hough ${ }^{1)}$ が多数例の川耳奇形の臨床例の 報告の中に豆状突起の筞全消失によって， I-S joint がわずかに軟組織でつながっている例を 挙げており，中耳炎の既往歴はなく中耳の他部 に炎症を思わせる所見は欠如しているものの， 幼小児期の中耳炎に起因するものであろうと推 察している. Miller ${ }^{2)}$ は, “hypermobility of I-S joint”という概念を提唱し，鼓膜正常で 原因不明の伝音難聴の中には，こう疾患があ り得るとしている。乙の場合，外観上は I-S joint は連結しており, 術中の注意媣い触診で のみ証明されるというが病因は明らかにされて いない. 村嶋ら ${ }^{3)}$ は, I-S joint がわずかの粗 膜によって連絡されていて，キ又夕骨の動きが アブミ骨に伝達されない状態の症例を報告し， 原因としては炎症が最も疑われると述べてい る.

今回報告したようなキ又夕省長脚の病理組織 学的所見は，すでに菅広の報告 ${ }^{4)}$ の中に一部が 记載されているものであるが，乙れらの䧗床例 の軽度のもの，あるいは前段階として理解する ことができ，いわば，潜在的㛊変であると思わ れる。

さて，乙れらの㤝変の成刚としては，まず炎 症が考えられよう。一般に中耳の炎症による耳 小骨の障害は，キヌタ骨長脚之豆状突起，アブ ミ骨脚と頭部に多いといわれる が障害を受け易い理由としては，皿流がそしい こと，長脚は中耳腔内にぶら下がるように位置 していること，などがあげられている，病理組 織学的には身体他部の骨䯣炎と同じく, vascu-

\section{察}

lar channel や骨䯣腔への炎症細胞浸潤と線維 化，骨膜の肥厚などがみられる。今回の標本の 一部に炎症細胞浸潤が認められたてとから，炎 症が関与しているものがあるととは明らかであ る.

もう一つの成因としては，开小骨の败造( remodelling）が考えられる。キヌタ骨の改造は 一生涯つづくもので，常に骨の吸収之再生がく り返されている ${ }^{6}$. Ghorayeb $^{7)}$ は， キヌタ周 の表面には度々このような骨吸収像がみられる ことを報告し，乙の状態に炎症や機械的刺激が 加わると障害が発生する一肉となり得るもの之 している，われわれの所見のうち，表層の吸收 像は最も度々みられたものであったが，てれら は remodelling の一過程を観察したものと考 えられる。

こうしたキヌタ肖の病変は，生前にかなりの 率で存在していることが明らかになった。この 出現頻度は，30才米満よりも30才以上に多くみ られたが，今までにあげられた原因である炎将: は幼小児期のことであるし，改造む加齢とは無 関係に継続する現象であるので，いずれも年令 との関連は考えられない。他に何らかの加㱓に よる直接的影響む原因となっていることを示し ているものと思われるが，現在のところ明らか でない.

いずれにせよ，このような病態が同:常中耳に 多数みられることは，この部に炎症や機械的刺 激が加えられた場合に病的状態を生じ易いとと が考えられるし，鼓膜生常な伝音難聴の中にこ のような病態のより強い変化を示したものが混 在する可能性を示唆しているものと考えられ る。

\section{ま と め}

ヒト側頭骨病理標本を観察し，44\%の例でキヌタ骨長脚に，さまざまな程度の骨吸収像を認め た。こ机らは，そ机白体では難聴の原闪とはなり得ないが，炎症や機械的刺激が加わると，容界に 


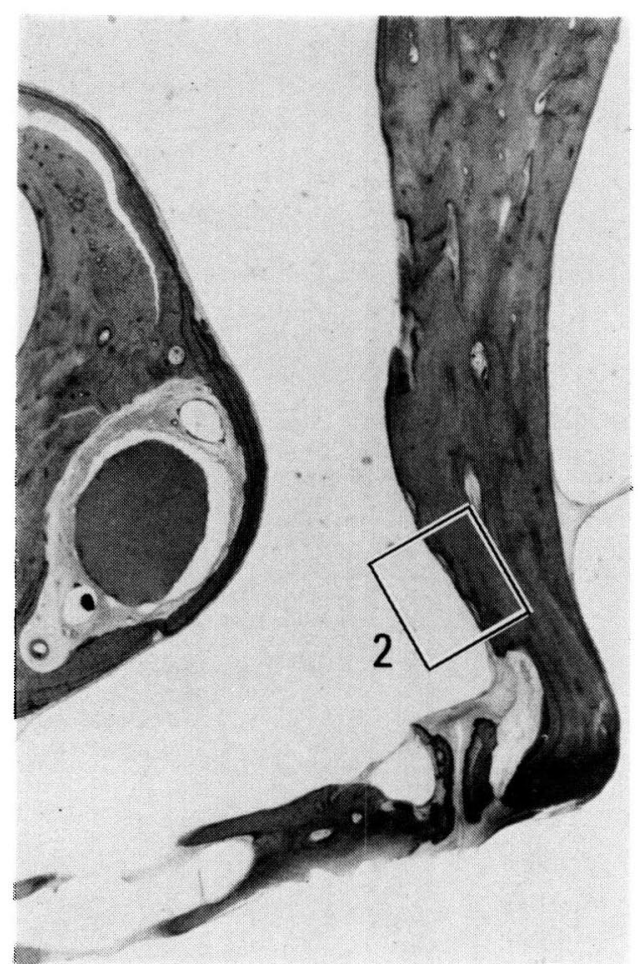

図 I

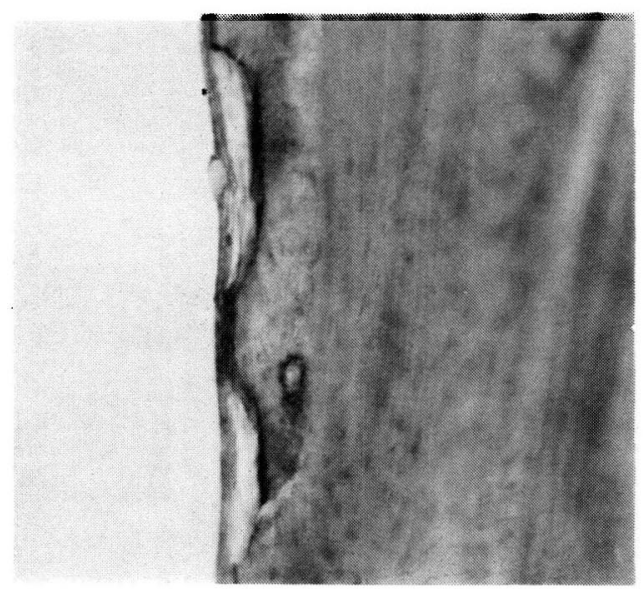

図 2

図 I長脚骨膜下には，しばしば限局性煘吸収像 が認められる。

图 2 限局性骨吸収像の昖大.

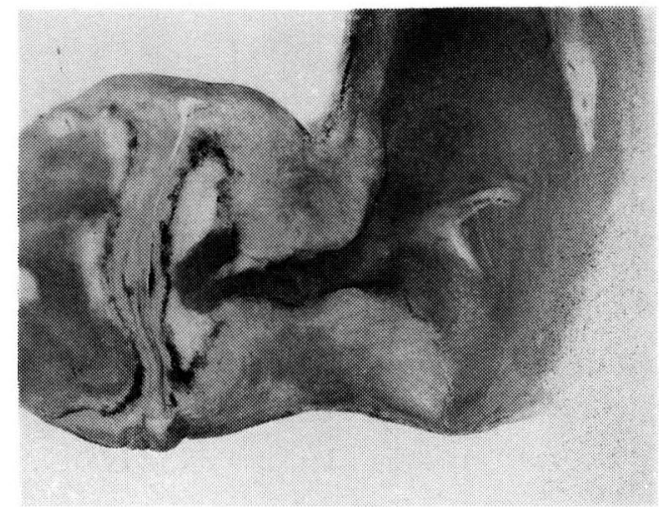

図 3

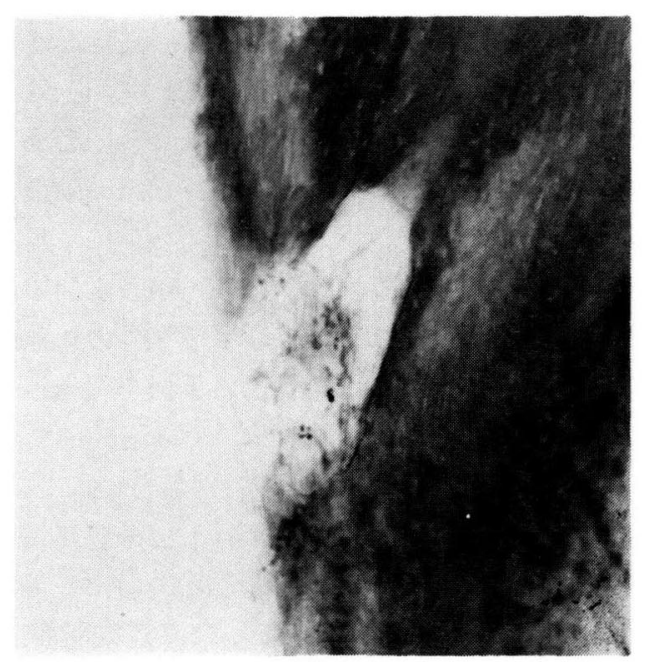

図 4

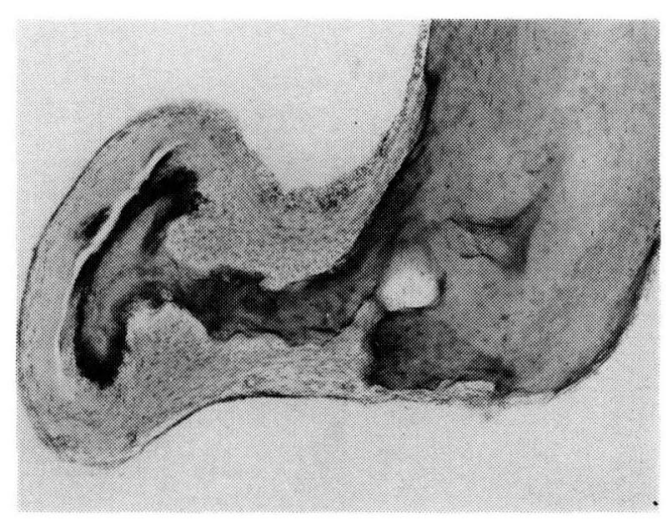

図 5

図 3，4，5 豆状突起を含む長脚先端部には， 比較的高度な骨吸収像がみられる。 


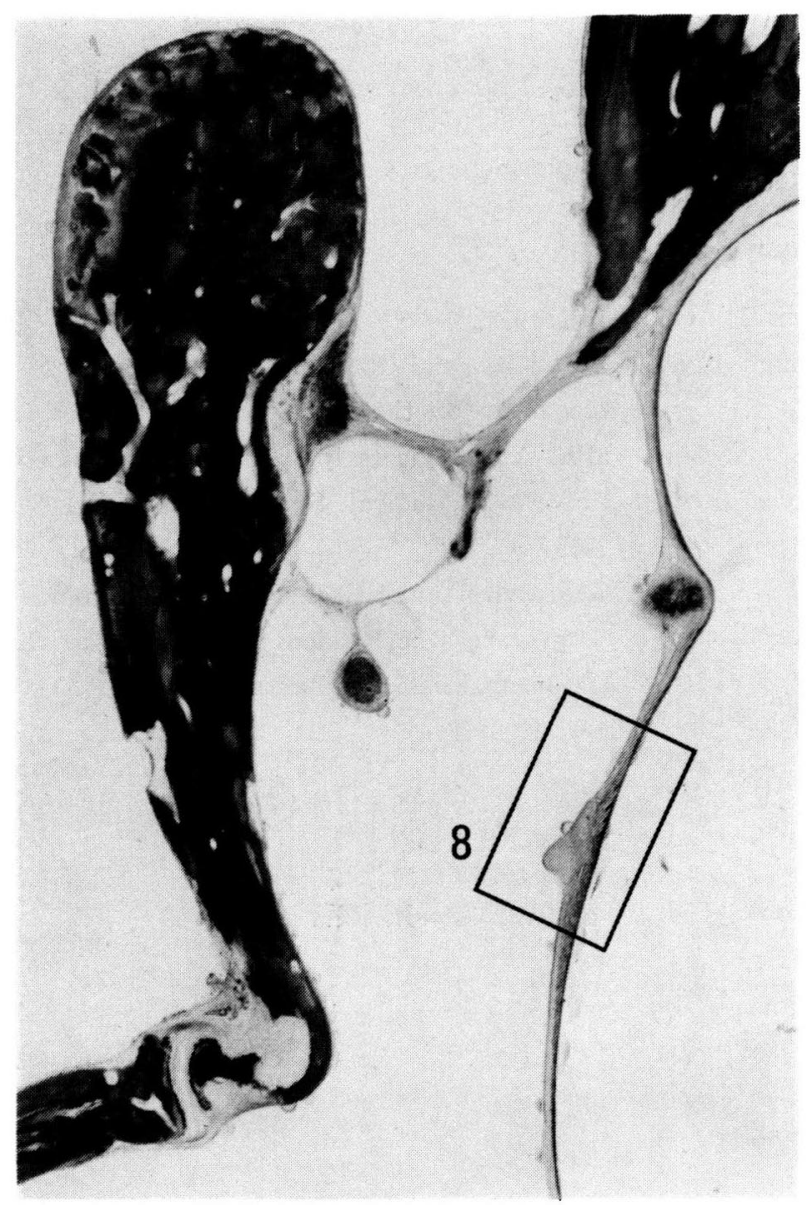

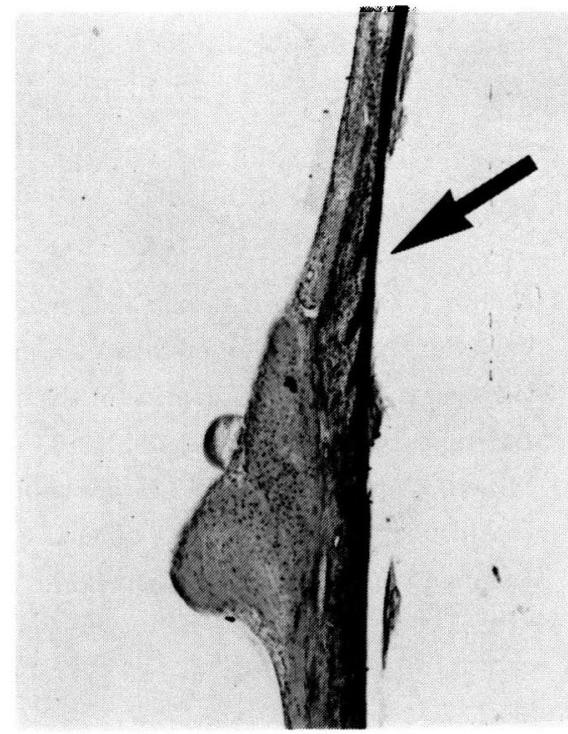

図 8

図 6,7

豆状突起の骨吸収像は，著しい場合 には，その骨質がほとんど消失して 線維組織で埋められている。

図 8

鼓膜皮膚層の配列の乱れがみられる (矢印).

图 6

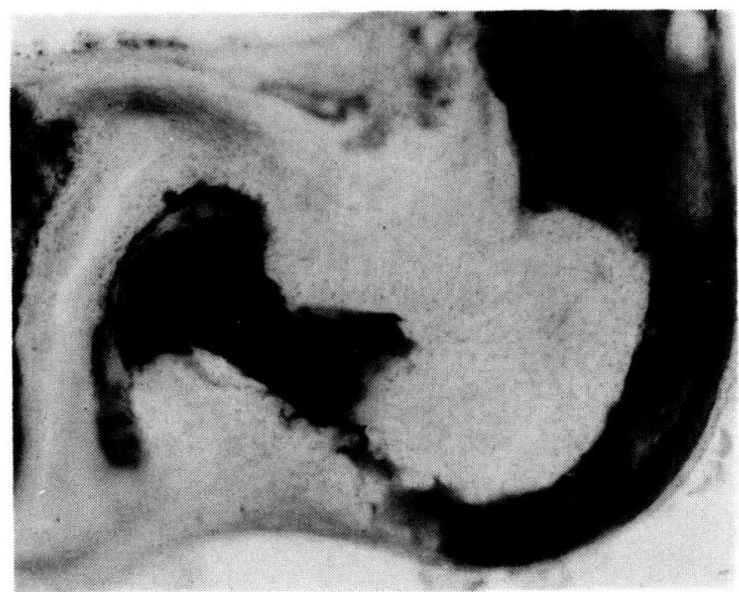

图 7 
速鎖離断などを生じ得る潜在的病変と考えられた。成因としては炎症，骨の改造（remodelling）， その他加秢の影響なども考えられると考察した。

病理標本の観察には，東京医科柬科大学秋吉正豊名誉教授の御指導をいただきました。㳭謝いたします。 本論文の内容の一部は, 第30回日本基礎耳科学会（大阪市）で報告した。

\section{考文 堿}

1) Hough JVD : Malformations and anatomical variatiơns seen in the middle ear during the operation for mobilization of the stapes. Laryngoscope $68: 1337 \sim 1379,1958$.

2) Miller GW and Keith RW : Hypermobility of the incudostapedial joint: A clinical entity? Laryngoscope 89:1943 1950, 1979.

3 ) 村沜竜太郎, 他：興味ある耳小骨異常を認めた鼓 膜正常の伝音難聴. 耳喉 $54: 75 \sim 77,1982$.

4 ）菅広 敬：中耳伝音系構造の変化汇関する病理組 織学的研究. 特にヒト側頭骨の耳小骨連鎖の病変 について. Audiology Japan 21:163〜176, 1978.

5) Pollock FJ : Pathology of ossicles in chronic otitis media. Arch Otolaryngol $70: 421 \sim$
435, 1959.

6) Anson BJ and Bast TH : Development of the incus of the human ear. Illustrated in atlas series. Quarterly Bulletin, Northwestern University Medical School 33: 110 119, 1959.

7) Ghorayeb BY and Graham MD : Human incus long process depressions in the surface of the normal ossicle. Laryngoscope $88: 1184$ $\sim 1189,1978$.

原稿到着：昭和 59 年 12 月 4 日 別刷請求先：小川 明 T920-02石川県河北郡内灘町大学1丁目1番地 金沢医科大学耳鼻咽喉科学教室 